\title{
Determinants of Market Participation of Enset (Ensete Ventricosum) producers: The case of Chena district, Kaffa zone, South western Ethiopia
}

\author{
Ejigu Mulatu* \\ Southern Agricultural Research Institute, Bonga Agricultural Research Center, Bonga, Ethiopia
}

*Corresponding author: Ejigu Mulatu, Southern Agricultural Research Institute, Bonga Agricultural Research Center, Bonga, Ethiopia

\begin{abstract}
Enset based farming is an indigenous agricultural system and more than $20 \%$ of Ethiopia's population depends on enset for food, feed, and fiber. Due to different factors, enset production is seemingly limited to consumption purpose and most of producers sold small amounts of products like Kocho, bulla and fiber.This study was conducted with major objective of: assessing determinants of market participation of enset producers in Chena district in Kaffa zone of south western Ethiopia. Two-stage sampling technique was employed to select four Kebeles and 101 representative enset producers. Both primary and secondary data sources were used to gather necessary data for analysis. Both descriptive statistics and econometric model were used to analyze the data. A Heckman two stage model was employed to assess the determinants of households' decision in market participation of enset products and the amount of gross income earned. Econometric model results showed that; sex, education level, livestock owned, distance from nearest market center, enset plantation, and transport access were found to be significant in influencing the probability of market participation decision. Furthermore, education level, family size, distance from nearest market cente, enset plantation, and transport access affected the amount of gross income earned from sale of enset products. The result suggests the need for stakeholders' involvement to enable market-oriented production of crop to capacitate farmers for better production and market supply to have increased amount of income and proper utilization of the crop.
\end{abstract}

Keywords: Determinants;Enset products; Farmers; Gross income; Heckman two stage

\section{Introduction}

In Ethiopia population of 79.3 million living in rural area being employed in agriculture [1], agriculture is the main driver for growth and long-term food security as it contributes on average 44.18\% share to GDP and $29.31 \%$ share for GDP growth from the year 2007/08 up to 2014/15 fiscal year [2].Enset based farming is an indigenous agricultural system and more than $20 \%$ of Ethiopia's population depends on enset for food, feed and fiber. Due to its drought tolerance, enset plant is regarded as a priority crop in Ethiopia, where it makes a major contribution to the food security of the country [3]. According to some reports, for instance, Elias (cited by [4]) revealed, enset crop is produced as a staple and co-staple food and represent a potential pathway to move out of poverty for many smallholders in Southern and South Western Ethiopia. Enset is a multi-purpose and multi-year crop with over $80 \%$ of its' production in the country is covered by the south and southwestern parts of the country. Enset is one of the indigenous root crops cultivated as traditional staple food crop and its' cultivation reaches about 65 percent of the total crop production in southern nation nationalities and people's regional state of Ethiopia [5]. During 2014/15 agricultural production year in Ethiopia, 345093 tone of kocho was supplied to market from Southern Ethiopia [6].

Market participation and commercialization involves the integration of a product or a household into a market economy. This integration may be expressed by an increased financial trade value 
or by the proportion of the sale to the total income. The success of product commercialization can be determined by factors external to small-scale farmers, including infrastructure, level of urbanization, technological change, and demand for the product as well as farm-level factors including size of landholding, extent of land use diversification, level of input use, and intensity of management. Thus, the commercialization of a product can be stimulated or deterred by factors ranging from household characteristics to broader institutional and policy environments [7].The main problem in Enset producer household is the inability to produce at a commercial scale and the loss of its product during processing, the improper storage of the final produce before consumption. In addition, enset production is highly affected by diseases, insect pests and vertebrates, the use of backward and inefficient traditional methods and equipment in production, processing and marketing activities, and low attention from existing extension component on protection and promotion of the crop[3],[8].

Moreover, it is clear observation that enset processing with traditional processing material is not easy task for women where there is no improved technology.Due to this conditions, enset production is seemingly limited to consumption purpose and most of farmers sold small amounts of products like Kocho, bulla and fiber[9]. Traditional or subsistent way of production, lack of improved harvesting, processing and value addition technology and expansion of other crop production let farmers to have little experience of money making from enset production. According to [10], different socioeconomic variables such as age of the household head, distance between the farmers' residence and the products market, livestock ownership, family size and area covered by enset were found to be important variables affecting kocho and bulla market participation by enset farmer households.

Chena district is one of potential enset producing areas in Kaffa zone as its' farming system is characterized by crop-livestock mixed farming with the two dominant perennial crops, Enset and coffee are grown in a friendly association with other crops [11]. Market imperfections in the are also challenged sustained enset farming and the conservation practices of the enset production. This was revealed through the existence of thin markets with few buyers and farmers with poor access to market information [12]. Despite the facts that enset remained staple crop in the area, little research and development attention have been given so far. As such potential of enset for food security and income generation, it has not been fully exploited by smallholder farmers [13]. It is required that farmers should produce not only for home consumption but also should have increased production and market supply with fair price for their product. Despite the importance of the enset crop to farm households, there was no study conducted in the district regarding market participation of enset producers. Thus, this study was needed to assess determinants of market participation of enset producers in Chena district of south western Ethiopia.

\section{Specific objectives}

a. To assess trend of enset production and its contribution to farm households' income

b. To identify factors influencing market participation and amount of income earned from sale of enset products

\section{Research Methodology \\ Description of the study area}

The study was conducted in chena district in kaffa zone of south western Ethiopia. The district is found at 510 and $785 \mathrm{~km}$ far from Addis Ababa and Hawassa, respectively. The district is located at

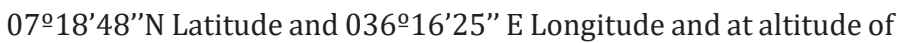
2020 m.a.s.l. It is bordered on the south by the Bench Majji zone, on the northeast by Gimbo, by Bita on the west, by Gewata on the north and on the east by Decha districts in Kaffa zone [14]. The district agro ecology is $15 \%$ high land, $80 \%$ midland and 5\% lowland. The district has a minimum temperature of $16^{\circ} \mathrm{C}$ and maximum temperature of $28^{\circ} \mathrm{C}$ with the annual mean rain fall of $1800 \mathrm{~mm}$. The total area coverage of the district reaches $901.92 \mathrm{~km} 2$ (Nuru, cited by [15]). The farming system of the district is characterized by crop-livestock mixed farming with the two dominant perennial crops enset and coffee are grown in a friendly association with other crops. Agriculture forms the major lifeline in the district as major crops grown include coffee, barley, enset, maize, sorghum, teff, faba bean, wheat, common bean and potato [11].

\section{Sampling techniques and sample size determination}

To select sample respondents, two-stage sampling was employed. In the first stage, four Kebeles from enset producing kebeles were selected purposively based on their potentials and accessibility in the condition that they represent the district. In the second stage, by taking the list of enset producing farmers from each selected Kebeles as a sample frame, 101 enset producers were randomly selected in probability proportion to size of each Kebele's population.

\section{Data sources and methods of collection}

In this study, both primary and secondary data sources were used to gather necessary data regarding the demographic and socio-economic profile of enset producers and situations of enset production and marketing. Structured questionnaire was used to generate the primary data from the selected sample producers. The primary data was collected from the selected sample respondents. In addition, focus group discussions (FGDs) and key informants' interview also used to gather necessary information to supplement data collected from selected respondents. Furthermore, secondary data was obtained from published and unpublished documents of different organizations including district office of agriculture and rural development, Non-Governmental Organizations (NGOs), Central Statistical Authority (CSA), and the like. 


\section{Data analysis}

The sample respondents' demographic and socio-economic conditions as well as enset production and marketing situations was analyzed using descriptive statistics like mean, standard deviations, frequency and percentage. Furthermore, the potential variables that are hypothesized to influence the farmers' market participation in sale of enset products were tested for statistical difference using t-statistics and Chi-square $\left(\chi^{2}\right)$ tests. The t-test was used to test the significance of the mean value difference of continuous variables between market participants and non-participants. Similarly, potential discrete (dummy) variables were tested using the Chisquare $\left(\chi^{2}\right)$ distribution for significance difference between the same group. Finally, determinants of farmers' market participation in sale of enset products and amount of gross income earned from sale of enset products was analyzed by using Heckman two stage model.

\section{The Heckman two-step procedure}

The preponderance of zeros for a number of the observations in a data set can lead to a number of econometric problems when using Ordinary Least Squares to estimate the unknown parameters of a regression model [16]. One of approach commonly used is the Tobit Model developed by James Tobin. In the Tobit model censoring is assumed to represent a standard corner solution and this in itself is a restrictive assumptionIn addition, Tobit model assumes the same variables affect the probability of participation decision as well as the level of a positive observation (the intensity decision) and moreover with the same sign is expected [17]. Another option is, double-hurdle model which assumes that two separate hurdles must be passed before a positive level of participation can be observed [18]. However, the presence of selectivity bias makes Heckman's sample selection model preferable as it works on the basis of the assumption of first hurdle dominance.This study used two-step Heckman's procedure to estimate determinants of farmers market participation and the level of participation. The first step of the Heckman's procedure involves estimation of the Probit equation to explain the participation decision and in the second step OLS estimation equation for level of participation is performed by using the selection bias control factor Lambda (predicted inverse Mills ratio) as an additional independent variable as it reflects the effect of all the unmeasured characteristics, which are related to the participation decision.

Participation equation specified using a binary decision model, a random variable $Y$ (dependent variable) takes the value of " 1 " if the household participates in enset products marketing and "0", otherwise. The probability of a household to participate on enset products marketing depends on a vectors of independent variables $\mathrm{X}_{\mathrm{i}}$ and a vector of unknown parameters $\beta$. The vector $\mathrm{X}_{\mathrm{i}}$ represents household heads demographic, socio-economic and institutional factors and the model is specified as follows:

$$
\begin{aligned}
& \mathrm{Y}_{1 \mathrm{i}}^{*}=\beta \mathrm{X}_{\mathrm{i}}+\varepsilon_{\mathrm{i}}, \varepsilon_{\mathrm{i}} \sim \mathrm{N}(0,1) \\
& \mathrm{Y}_{\mathrm{i}}=\left\{\left(1 \text { if } \mathrm{Y}_{\mathrm{i}}^{*}>0 @ 0 \text { if } \mathrm{Y}_{\mathrm{i}}^{*} \leq 0\right)\right.
\end{aligned}
$$

Where, $\mathrm{Y}_{1 \mathrm{i}}{ }^{*}$ is a latent (unobservable) variable representing households' discrete decision whether or not to participate, $\mathrm{x}_{\mathrm{i}}$ is a vector of independent variables hypothesized to affect household's decision of participation, $\beta$ is a vector of parameters to be estimated; $\varepsilon_{\mathrm{i}}$ is the random error term (Table 1 ).

\begin{tabular}{|c|c|c|c|c|}
\hline \multirow{2}{*}{ Variables } & \multirow{2}{*}{ Descriptions of variable } & \multirow{2}{*}{ Types } & \multicolumn{2}{|c|}{ Expected Relation } \\
\hline & & & Participation & Intensity \\
\hline \multicolumn{5}{|c|}{$\begin{aligned} \text { Dependents } \\
\end{aligned}$} \\
\hline MRKTPART & Market participation (yes $=1, \mathrm{No}=0$ ) & Dummy & & \\
\hline LEVLPARTC & Gross income from sale of enset products in birr & Continuous & & \\
\hline \multicolumn{5}{|l|}{ Independents } \\
\hline SEX & Sex of household head (male $=1$, female $=0$ ) & Dummy & + & + \\
\hline AGE & Age of the household head & Continuous & + & + \\
\hline EDUCATION & Education level of household head & Continuous & + & + \\
\hline FAMSIZE & Family size & Continuous & - & - \\
\hline ENSETLAND & Area coverage of enset plantation (timad) & Continuous & + & + \\
\hline LIVESTOCK & Livestock ownership in TLU & Continuous & - & - \\
\hline LANDSIZE & Land size (ha) & Continuous & + & + \\
\hline DISTANCE & Distance to nearest market $(\mathrm{Km})$ & Continuous & - & - \\
\hline EXTENSN & Access to extension service (yes $=1, \mathrm{No}=0$ ) & Dummy & + & + \\
\hline MRKTINFO & Access to market information (yes $=1, \mathrm{No}=0$ ) & Dummy & + & \\
\hline TRPRTACCES & Access to transport (yes $=1, \mathrm{No}=0$ ) & Dummy & + & + \\
\hline
\end{tabular}

Table 1: Summary of definitions of variables and working hypotheses.

NB: 8 timads equivalent with a hectare 
In the second step, OLS estimation equation for level of participation is specified as follows

$$
Y_{2 i}=\gamma_{0}+\gamma_{i} X_{i}+\mu_{i} \lambda_{i}+\eta_{i} \eta_{i} \sim N\left(0, \delta^{2}\right)
$$

Where, $Y_{2 \mathrm{i}}$ isthe amount of gross income from sale of enset products in the second step; $X_{i}$ are the explanatory variables determining the amount of gross income from sale of enset products; $\gamma_{i}$ are unknown parameters that estimated in the amount of gross income; $\mu_{\mathrm{i}}$ is a parameter that shows the impact of selectivity bias on the amount of gross income from sale of enset products ; $\eta$ is the error term.

\section{Results and Discussion}

\section{Sample households' characteristics}

The Mean age of the total sample households was 45.72 years. Mean age of market participant group was 47.53 years $(S D=10.70)$. By comparison, non-participant group was associated with numerically lower age of 42.59 (SD=8.81). The result of independent

Table 2: Descriptive result of sample households' characteristics. sample t-test showed that, there was statistically significant difference between mean of two groups at $5 \%$ level of significance. The Mean education level of the total sample households head was 3.27 years. Mean education level of market participant group was 4.375 years ( $\mathrm{SD}=3.917)$. By comparison, non-participant group was associated with numerically lower mean education level of 1.37 years $(S D=2.19)$ and there was statistically significant mean difference between two groups at $1 \%$ level of significance.

The Mean land size of the sample households was 2.48 hectares. Mean land size of market participant group was 2.16 (SD=1.38). By comparison, non-participant group was associated with numerically higher mean land size of 2.43 (SD=1.26); but the difference was not statistically significant. The enset products market participants have higher mean enset plantation than non-participants. In addition, participants walk lower mean market distance than non-participants. There was statistically significant difference in mean enset plantation and market distance between two groups at $1 \%$ and $5 \%$ level of significance respectively (Table 2).

\begin{tabular}{|c|c|c|c|c|c|c|c|}
\hline \multirow{2}{*}{ Continuous variables } & \multicolumn{2}{|c|}{ Non-participants $(\mathrm{N}=40)$} & \multicolumn{2}{|c|}{ Participants $(\mathrm{N}=61)$} & \multirow{2}{*}{ t- value } & \multicolumn{2}{|c|}{ Total sample $(\mathrm{N}=101)$} \\
\hline & Mean & SD & Mean & SD & & Mean & SD \\
\hline Age & 42.59 & 8.81 & 47.53 & 10.70 & $-1.98^{* *}$ & 45.72 & 10.22 \\
\hline Education & 1.37 & 2.190 & 4.375 & 3.917 & $-4.27^{* * *}$ & 3.278 & 3.674 \\
\hline Land size & 2.43 & 1.268 & 2.16 & 1.389 & 0.951 & 2.482 & 1.98 \\
\hline Livestock in TLU & 4.84 & 2.81 & 4.24 & 2.013 & 1.247 & 4.46 & 2.34 \\
\hline Enset plantation (timad) & 1.12 & 0.70 & 1.87 & 0.906 & $-4.10^{* * *}$ & 1.608 & 0.896 \\
\hline Market distance (km) & 7.89 & 2.536 & 5.04 & 2.339 & $5.72^{* * *}$ & 6.087 & 2.77 \\
\hline \multicolumn{8}{|c|}{ Discrete variables } \\
\hline Category & \multicolumn{2}{|c|}{ Percent } & $\chi^{2}$ value & \multicolumn{2}{|c|}{ Percent } & \multicolumn{2}{|c|}{ Percent } \\
\hline Sex (\% female) & 8.3 & & 91.70 & & $10.86^{* * *}$ & 23.80 & \\
\hline Transport access (\% yes) & 15.90 & & 84.10 & & $14.42^{* * *}$ & 56.40 & \\
\hline Access extension (\% yes) & 25.00 & & 75.00 & & $7.328^{* *}$ & 55.40 & \\
\hline
\end{tabular}

*** and ** represent significance at $1 \%$ and $5 \%$ respectively

Source: Own survey data (2016)

The sample was composed of both male and female-headed households. From the total sample households, 23.8 percent were female headed households. From female headed households, 91.7 percent were market participant and only 8.3 percent were nonparticipants. The result of Chi-square test statistic showed the difference in terms of sex of household head between the two groups was significant at $1 \%$ level of significance. From the total sample households, 56.4 percent had transport access and the remaining had no access. The difference in terms of transport access between the two groups was significant at $1 \%$ level of significance (Table 2).From the total sample households, 55.4 percent had access to extension contact on enset production and marketing and the remaining had no access. The difference in terms of access to extension contact between the two groups was significant at $5 \%$ level of significance.

\section{Enset production trend (Of year 2011/12-2015/16)}

Sample respondents were asked to describe trend of enset plantation on their farms for the last five consecutive years (Figure 1). The survey result showed that the average amount of land coverage by enset plantation per a farmer has been decreased from year of 2011 of mean of 1.71 timad to 1.61 timad of the year 2015/16 (8timad equivalent with a hectare). Different factors such as diseases, insect pests and vertebrates, lack of soil fertility, expansion of other crops, the use traditional production and processing techniques and lack of favorable market with attractive 
incentives were some of reasons respondents mentioned for decreasing enset production.Some reports showed that due to these problems enset production is seemingly limited to consumption purpose and this resulted in low participation of producers in the market [9],[3].

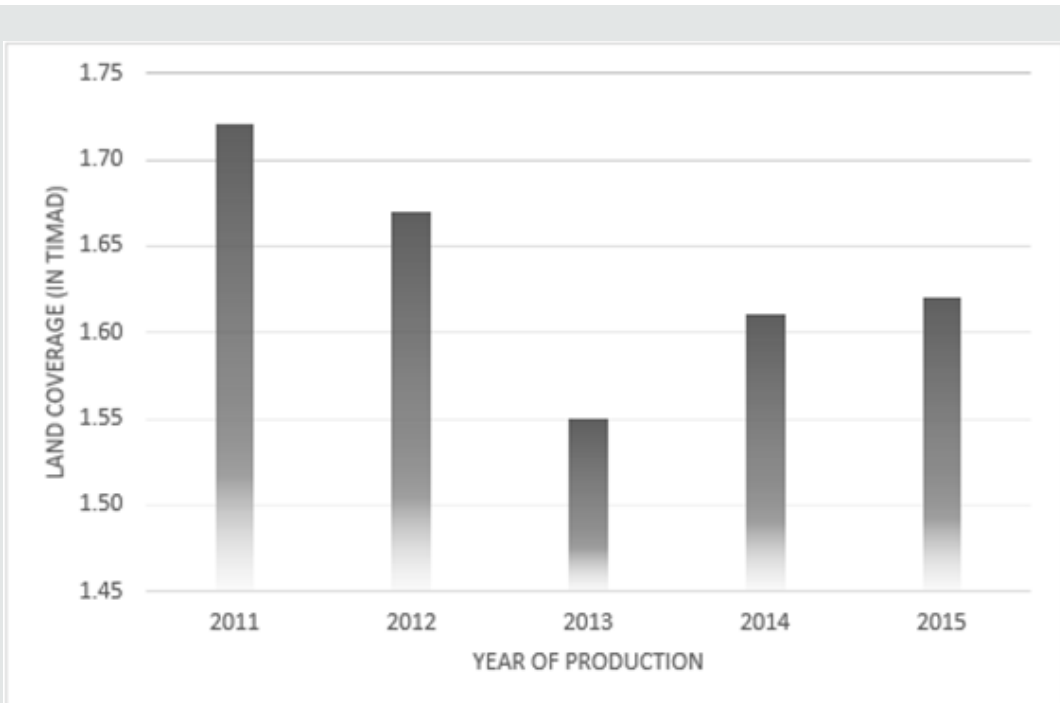

Figure 1: Trend of enset plantation at household level (NB: 8 timads equivalent with a hectare)

Source: Own survey data (2016).

\section{Households participation in sale of enset products}

The experience of farm households in making money from sale of enset products was low as nearly 40 percent of sample households didn't sale any enset product in a year 2014/15. The practice of processing and marketing of enset products was mainly associated with women and males' participation at this stage was low as most of male farmers have no knowledge about it. Seemingly, this condition affected the sector to be less competent with other crops and resulted in low level of commercialization of enset production, despite the commodity could be additional source of income for farm households.In this study, four available options that a household used were assessed. These options were; sale of enset products like Kocho, bulla, fiber, and enset plant itself for other processors. Most of farm households who participated in sale of enset products sold kocho and few farmers participated in sale of other products. Some of respondents showed the perception that; since extraction of bulla affects kocho quality, they didn't process bulla separately. Due to this condition, only few farm households processed bulla and supplied to the market. The experience of households in extracting fiber and using it for money making and other service was weak.

Despite sale of enset plant could be used as other income source and it was better practiced by some of male household heads than other enset products, only few households used to make money from sale of enset plants for other processors. From sample households who participated in sale of enset products in the year, 31 percent earned the amount less than 500 birr. Only 15 percent got the annual amount of more than 2000 birr and the rest of sample households earned the amount between 500 up to 2000 birr (Table 3).

Table 3: Hosehold's income from sale of enset products (2014/15).

\begin{tabular}{|c|c|c|}
\hline Income category (birr) & Frequency & Percent \\
\hline 0 & 40 & 39.6 \\
\hline $1-500$ & 19 & 18.8 \\
\hline $501-1000$ & 18 & 17.8 \\
\hline $101-2000$ & 15 & 14.9 \\
\hline$>2001$ & 9 & 8.9 \\
\hline Total & 101 & 100.0 \\
\hline
\end{tabular}

Source: Own survey data (2016).

\section{Factors Affecting Households' market Participation}

\section{Determinants of market participation}

From 11 explanatory variables expected to affect households' market participation, those variables which found to be significant were discussed under this section as follows(4). Sex of household head showed negative relation with market participation of enset products and significant at 5\% level of significance. The model output showed that, if a dummy changed from being male to female headed households, the probability of households' participation in marketing of enset products increases by $24.7 \%$ ceteris paribus. This might be due to the reason that, men usually own larger farm lands and have better practice of income diversification compared to women. In the area, enset was mainly produced for home consumption and in the condition that a household had alternative 
income sources, money making from sale of enset product was low. Due to this condition female headed households were more market participant than male headed households. Similarly, [4] showed that the female-headed households are more market oriented than male headed and participate more in the marketing of enset products as also kochoproduction and business is mostly gender specific.

Education level of household head affected market participation positively and significant at $1 \%$ level of significance. A one-year increase in education level increases the probability of household's market participation by $6 \%$, keeping the other things remain constant. This is because, being literate may put households in a relatively better position to gather, understand and realize information on production and marketing of enset products.

Livestock ownership affected enset products market participation decision and significant at $10 \%$ level of significance. The result from the marginal effect revealed that, a unit increase in livestock ownership in TLU decreases the probability of household's market participation by $6 \%$, keeping the other things constant. This is because, having more livestock owned creates better opportunity for diversified source of farm income as livestock is considered as liquid asset. Due to this reason households who have more livestock showed lower participation in sale of enset products. The finding is consistent with [19]who showed farmers with more TLU tend to specialize in livestock production reducing the importance crop production as means of cash generation. However, it is contrary to [4] who showed positive relation between livestock ownership with enset production and marketing.

Distance from households' residence to nearest market center is significant at $10 \%$ level of significance in postive relation with market participation decision. The result showed that a onekilometer increase in distance from the nearest market decreases the probability of household's participation in the market by $4.6 \%$, assuming the other things remain constant. This is because farm households' residence far away from the market center coupled with the product nature like heavyweight per unit volume of the products discourages some farmers to supply enset product, like kocho, to the market. The finding is consistent with [10]and [4].

Area under enset plantation showed negative relation with market participation decision and significant at $1 \%$ level of significance. The model output showed that increase in area under enset plantation by one timad increases the probability of households' participation in marketing of enset products by $87 \%$ ceteris paribus. This might be due to having more enset plantation covers households' consumption need and allows to supply surplus of harvest to the market and increases probability of market participation. This is in line with this [10] who showed positive relation between variables.Transport access affected probability of market participation positively and significant at $1 \%$ level significance. The model output showed that if a household had transport access, probability of market participation of enset products increases by $29.1 \%$. This is due to the product nature that heavyweight per unit volume of the product discouraged some farmers to supply kocho product to the market if they lacked transport access(Table 4).

Table 4: First-stage probit estimation results of the determinants of kocho market participation

\begin{tabular}{|c|c|c|c|}
\hline Variables & Coefficient & $\mathbf{z}$ & Marginal effect \\
\hline Sex & $-1.627^{* *}$ & -2.35 & -0.247 \\
\hline Age & 0.040 & 1.33 & 0.009 \\
\hline Education & $0.254^{* * *}$ & 2.87 & 0.060 \\
\hline Family size & -0.153 & -1.42 & -0.036 \\
\hline Land size & 0.021 & 0.15 & 0.005 \\
\hline Livestock (TLU) & $-0.255^{*}$ & -1.80 & -0.060 \\
\hline Distance to market & $-0.198^{*}$ & -1.94 & -0.046 \\
\hline Enset plantation & $7.991^{* * *}$ & 2.73 & 0.870 \\
\hline Extension contact & 0.654 & 1.41 & 0.159 \\
\hline Transport access & $1.344^{* * *}$ & 2.62 & 0.291 \\
\hline Market information & 2.016 & 1.34 & 0.206 \\
\hline Constant & 0.183 & 0.10 & \\
\hline \multicolumn{2}{|c|}{ Number of observations $=101$} & \multicolumn{2}{|c|}{ LR $\operatorname{chi} 2(11)=84.47$} \\
\hline \multicolumn{2}{|c|}{ Log likelihood $=-24.118$} & \multicolumn{2}{|c|}{ Prob $>$ chi $2=0.0000$} \\
\hline \multicolumn{2}{|c|}{ Pseudo R2 = 0.636} & & \\
\hline
\end{tabular}

*** , ** and * represent significance at $1 \%, 5 \%$ and $10 \%$, respectively Source: Own survey data (2016).

\section{Factors affecting the amount of gross income from sale of enset products}

Table 5: Results of the second-stage Heckman selection model.

\begin{tabular}{|c|c|c|c|}
\hline Variables & Coefficient & Standard error & $\mathbf{z}$ \\
\hline Constant & 3551.59 & 702.306 & 5.06 \\
\hline Age & -3.774 & 6.228 & -0.61 \\
\hline Sex & -73.01 & 246.80 & -0.30 \\
\hline Education & $90.45^{* * *}$ & 28.626 & 3.16 \\
\hline Family size & $-310.75^{* * *}$ & 52.136 & -5.96 \\
\hline Land size & 62.399 & 48.623 & 1.28 \\
\hline Livestock owned & -34.43 & 58.77 & -0.59 \\
\hline Enset plantation & $561.10^{* * *}$ & 118.70 & 4.73 \\
\hline Market distance & $-175.053^{* * *}$ & 47.43 & -3.69 \\
\hline Extension contact & 322.427 & 195.47 & 1.65 \\
\hline Transport access & $376.78^{*}$ & 215.08 & 1.75 \\
\hline Mills lambda $(\lambda)$ & $222.35^{* * *}$ & 65.45 & 3.397 \\
\hline Rho & 1.00 & & \\
\hline Sigma & 222.89 & & \\
\hline \multicolumn{2}{|c|}{ Number of observations $=101$} & \multicolumn{2}{|c|}{ Uncensored observation $=61$} \\
\hline \multicolumn{2}{|c|}{ Censored observations $=40$} & \multicolumn{2}{|c|}{ Wald chi2(10) = 239.86} \\
\hline \multicolumn{2}{|c|}{ Log likelihood $=-514.7537$} & \multicolumn{2}{|c|}{ Prob $>$ chi2 $=0.0000$} \\
\hline
\end{tabular}

$* * *, * *$ and * represent significance at $1 \%, 5 \%$ and $10 \%$, respectively

Source: Own survey data (2016) 
From 10 explanatory variables expected to affect gross income earned from enset products, five variables found to be significant (Table 5).Education level of household heads affected the amount of gross income from sale of enset products positively and significant at $1 \%$ level of significance. For a one-year increase in education, the gross income from enset products increases by 90.45 birrs, ceteris paribus. This might be due to the reason that households who were educated tend to be more capable of exploring relevant information about enset production and marketing as they produce in better market-oriented way than household heads with lower education level.Family size affected the amount of gross income from sale of enset products negatively and significant at $1 \%$ level of significance. For a unit increase in family size, the gross income from enset products decreases by 310.75 birrs, ceteris paribus. This negative relation was as a prior expectation because enset was mainly produced for home consumption and those households with higher family size supplied lower surplus amount and earned lower gross income.

Land size of enset plantation affected the amount of gross income from sale of enset products positively and significant at $1 \%$ level of significance. For a one timad increase in plantation of enset, the gross income from sale of enset products increases by 561.10 birrs, ceteris paribus. Since the enset crop was considered to be cultivated as traditional staple food crop, the amount of land covered by enset plantation majorly determined surplus production and supply of enset plants to the market. Due to this reason farmers who owned larger land size of enset plantation earned more income than those with small size of enset plantation. The finding is consistent with [10] who showed household with greater area under enset plantation will have more of matured enset to be harvested and the surplus of kocho and bulla to be supplied to the for market.

Distance from households' residence to nearest market center showed negative relation and significant at $1 \%$ level of significance. The result showed that a one-kilometer increase in distance from the nearest market decreases the amount of income from sale of enset products by 175.05 birr, assuming the other things remain constant. This is because farm households' residence far away from the market center and the heavyweight per unit volume of the product discourages some farmers to supply more enset product to the market than those living nearer to the market. Due to these conditions farm households residing near to market center supplied more products and earned more income than those living far.The finding is consistent with [10].Transport access affected the amount of gross income from sale of enset products positively and significant at $10 \%$ level of significance. The model output showed that if a household had transport access the annual income from sale of enset products increases by 376.78 birr, assuming other things remain constant. This is due to the product nature that heavyweight per unit volume of the product discouraged some farmers to supply kocho product to the market if they lacked transport access.

\section{Conclusion and Recommendations}

Enset in the chena district is major indigenous root crop cultivated as traditional staple food crop. However, its area coverage at farm level has been decreasing for the last five years due to various reasons. Some of such factors include; diseases, insect pests and vertebrates, lack of soil fertility, expansion of other crops, the use traditional production and processing techniques and lack of favorable market with attractive price. Moreover, enset production was considered as mainly for consumption purpose and farmers participation in marketing of enset products was weak for various reasons. Econometric model result showed that sex, education level, livestock owned, distance from nearest market center, enset plantation, and transport access were found to be significant in influencing the probability of market participation decision. In addition, education level, family size, distance from nearest market center, enset plantation, and transport access affected the amount of gross income from sale of enset products.

The problems related with harvesting, processing, and marketing of enset products was its limitation to traditional equipment and methods. Women faced lack of improved harvesting and processing technology in the area and that affected their capacity and performance. Therefore, it would be better if district agricultural office in collaboration with research centers and other concerned bodies work on introduction, demonstration and widely dissemination of improved technology around enset processing and marketing in the area.Even though enset production was considered as mainly for consumption purpose in the district, it could also be potential source of farm income for producers. Therefore, different stakeholders' involvement is needed to establish market-oriented production of enset crop through capacitating farmers for better production and market supply to have higher amount of income from the commodity and assuring provision of considerable income diversification source. The existing marketing system and lack of market information coupled with awareness problems made most of male headed households to stay far away from participation in marketing of enset products. To have increased participation of farmers and make the enset crop as additional source of farm income for producers, establishing favorable market, market promotion and dissemination of market information for producers is needed.

\section{References}

1. FAO (2015) Statistical pocketbook2015. Food and Agriculture Organization. Rome.

2. National Bank of Ethiopia (NBE). 2014/15. National Bank of Ethiopia Annual report of year 2014/15.

3. Mohamed Y, Tariku H (eds.) (2012) Enset Research and Development Experiences in Ethiopia. Proceedings of Enset National Workshop, 1920 August 2010, Wolkite, Ethiopia. 
4. Lefebo N, Jema H, Geta E, Zemedu L (2016) Determinants of status and extent of Market Participation among kocho Producers in Hadiya Zone, Southern Ethiopia. International Journal of Agricultural Research and Review 4(2): 476-485.

5. Birmeta G, Nybom H, Bekele E (2004) Distinction between wild and cultivated enset (Enset ventricosum) gene pools using RAPD markers in Ethiopia.

6. CSA (Central Statistical Authority) (2015) Agricultural sample survey of Ethiopia. Report on area and production of major cops. Addis Ababa, Ethiopia.

7. Strasberg PJ, Jayne TS, Yamano T, Nyoro J, Karanja D, et al. (1999) Effects of agricultural commercialization on food crop input use and productivity in Kenya. Michigan State University International Development Working Papers No. 71. Michigan, USA.

8. JM Wooldridge (2002). Econometric Analysis of Cross Section and Panel Data. Cambridge, MA: MIT Press

9. Alemayehu A (2018) The Role of Women in Enset Market Chain the Cause of Dawuro Zone, Southern Nations Nationalities and Peoples Regional State, Ethiopia. Int J Curr Res Aca Rev 6(4): 36-47.

10. Tessema E, Bosena T, Lemma Z (2017) Determinants of Market Participation of Enset (Ensete Ventricosum) Farmers: The Case of Doyogena District, SNNPR, Ethiopia. Journal of Economics and Sustainable Development 8(15).

11. Chena District Office of Agriculture and Rural Development (CDOARD) (2015) Report on socio economic profile and background information of the district.
12. Tsehaye Y, Kebebew F (2006) Diversity and cultural use of enset (Enset ventricosum (Welw.) Cheesman) in Bonga in-situ Conservation Site, Ethiopia, Ethnobot 4: 147.

13. Belachew G, Aklilu A, Bewuketu H, Habtamu K (2017) Indigenous Knowledge of Enset (Ensete ventricosum (Welw.) Cheesman) Cultivation and Management Practice by Shekicho People, Southwest Ethiopia. Journal of Plant Sciences (1): 6-18.

14. Kifle B, Mebratu G, Kumlachew A (2015) Integrated management of common bacterial blight (Xanthomonas axonopodis pv. Phaseoli) of common bean (Phaseolus vulgaries) in Chena district of Kaffa zone, Southwest Ethiopia. Malays. J Med Biol Res 2(2): 147-152.

15. Kassa T, Jema H, Bosena T (2018) Factors affecting market supply of honey in Chena district, Kaffa zone, Southern Ethiopia. Journal of Development and Agricultural Economics10(3): 99-109.

16. W. Greene. (2003). Econometric analysis, volume 3. Prentice Hall Upper Saddle River, NJ.

17. Tobin J (1958) Estimation of relationships for limited dependent variables. Econometrica 26: 24-36.

18. Wooldridge JM (2002) Econometric Analysis of Cross Section and Panel Data. Cambridge, MA: MIT Press.

19. Rehima M (2006) Analysis of red pepper marketing: The case of Alaba and Siltie in SNNPRS of Ethiopia. M.Sc thesis presented to the School of Graduate Studies, Haramaya University. 105p.

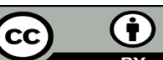

This work is licensed under Creative Commons Attribution 4.0 License

To Submit Your Article Click Here:

Submit Article

DOI: $10.32474 /$ CIACR.2020.08.000298

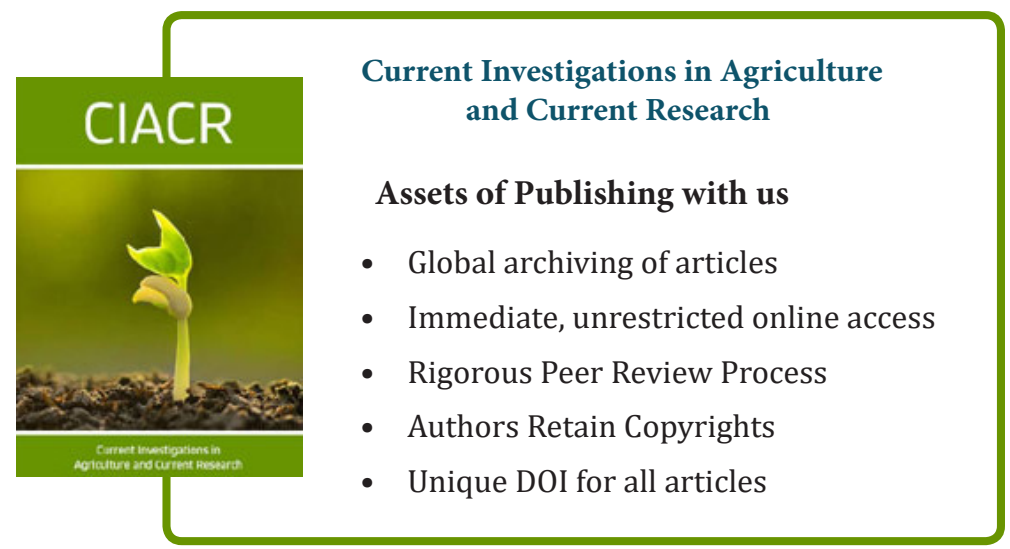

